\title{
How Important It Is to Produce Seeds for The Aquaculture of Bivalve Molluscs?
}

\author{
Tatiana N Olivares-Bañuelos* \\ Instituto de Investigaciones Oceanológicas, Universidad Autónoma de Baja California, México
}

Submission: September 07, 2018; Published: September 27, 2018

Corresponding author: Tatiana Nenetzen Olivares Bañuelos, Instituto de Investigaciones Oceanológicas Universidad Autónoma de Baja California, Carretera Tijuana-Ensenada No. 3917, Fraccionamiento Playitas 22860 Ensenada, Baja California, México; Tel: + 52-646-1750707 (Ext. 64176); Email: tatiana.olivares@uabc.edu.mx

\begin{abstract}
Fishery products are an important part of the diet in many countries of the world, where demand increases proportionally with population growth. The greater request of seafood products refers to fish, however, the production and harvest of molluscs, especially bivalves, will also play a key role in satisfying this growing market. To meet this demand, it is necessary to have an available number of organisms, which may be the product of either fishing or aquaculture. Nevertheless, there are not enough studies about the biological and ecological characteristics of these resources that guarantee maintainable production. This makes it difficult to carry out sustainable and adequate exploitation of the natural wealth. Alternatives involve either the repopulation of natural banks or the seed production, which can be used in aquaculture farming's for the production of bivalves until their commercial size. In either case, it is necessary to continue researching in the biology of the bivalves and innovating working methods to produce mollusc seeds and meet the demands of the emergent market.
\end{abstract}

Keywords: Shellfish aquaculture; Splat production; Farming of bivalves; Sustainable mollusc fishing

\section{Introduction}

Bivalve molluscs (oysters, mussels, clams, and scallops) are an important part of the world's fishing production. According to the most recent statistics compiled by the FAO, worldwide aquaculture production in 2014 reached the historical maximum of 73783.7 thousand tons (live weight), with a value of 160.200 USD million [1]. Of these, $21.8 \%$ (16.1 million tons) corresponded to molluscs with a market value of 19.000 USD million. The fact that more than a fifth of the world's aquaculture production refers to bivalves, indicates that this group of organisms is relevant in the daily diet of the population.

Bivalves are ideal for aquaculture since they are herbivores that require minimal management in the laboratory, and do not need more food than microalgae that are naturally found in seawater [2]. Although they have been cultivated for centuries, recent technological advances in the field of mollusc farming have allowed increasing their production significantly. Farming methods and technologies require constant improvement in order to meet growing demand and to make bivalve farming an economically attractive activity for investors and those wishing to start in that activity. In order to achieve successful cultivation, it is vital to improve the efficiency of aquaculture activities.

First, it is important to consider that in the world the areas where mollusc farming can be practiced are limited, and it will be increasingly difficult to find new sites for this activity due to the demographic pressure and the urban development of the coasts
[2]. Second, the capture of natural bivalve banks will continue to be important. In many of the natural populations where is practiced the mollusc seed capture, organisms are already close to the maximum sustainable limits, and in some places they have already surpassed them. This situation can be alleviated through aquaculture techniques, which offers an alternative to the exploitation of natural populations [3].

Currently, in most of the world's bivalve farms, seeds are collected in natural banks (areas of natural abundance), and the substrate (fixing material) is placed in the hatchery tanks during the breeding process. The larvae are collected in metamorphosis and transferred to the hatcheries until it reaches a commercial size. Having an abundant, reliable and low-cost seed is an essential requirement for any marine cultivation or exploitation activity. Seed collection in areas of natural recruitment will continue to be important for bivalve farms, and undoubtedly, in some areas this practice may be intensified to meet the increased demand. It must be remembered that in many farming areas, there are not natural breeding zones that supply the necessary bivalve seeds for commercialization. In other zones, producers develop and cultivate specific varieties of bivalves that fit their particular needs, sometimes introducing non-allochthonous (exotic) species, for which they do not have a constant source of seed. For this reason, it is necessary to recognize the importance of the natural breeding areas and make a great effort to conserve 
them, repopulate them or, failing that, to look for alternative methods that allow us to continue obtaining bivalves without affecting the ecosystems.

One of the best alternatives consists of harvesting in natural bivalve banks or producing the seeds in hatcheries or farms. Bivalve hatcheries have been in operation for more than sixty years, and are now well established in many countries. They form an integral part of many farms and constituting the largest or only source of seed [4]. In order to optimize the performance in breeding sites, it is sought to extend as much as possible the duration of the reproductive period of the broodstock adults using conditioning methods. The purpose of the conditioning is to enhance the fecundity of the parents, the quality of the eggs and the larval viability [5]. Conditioning techniques are based on stabling environments of optimum temperature and abundance of food. The adequate conditioning of the broodstock leads to the generation of seeds throughout different times of the year. If the seeds are produced at the beginning of the cycle, in colder climates, it ensures that the seed will have a maximum growth period before the first winter. Seeds produced under these circumstances will be larger and more resistant to low temperatures.

Undoubtedly now and in the future, bivalve hatcheries will play a very important role in the set of aquaculture activities, as shellfish exploitation becomes specialized and the demand for seed increases [2]. Bivalve hatcheries offer several advantages over harvesting in natural banks, as they are reliable and can supply seed to farmers according to their requirements and when convenient, often much earlier in the growing season than with natural banks. Besides, they can provide specific seeds that are not available in natural banks, as is the case of either exotic or genetic varieties with improved biological characteristics for its exploitation in local areas. The cost is the principal disadvantage of the seed production in the hatchery. It is more expensive to grow the seed in a farm facility, than collect it from a natural bank. Even if in the past economic factors have probably been the cause of the failure of some bivalve hatcheries, recent technological improvements have greatly enhanced their reliability and economic viability. Now it is possible to produce seed at competitive prices, and in fact, in some parts of the world, hatcheries are the only source of seed for the commercial aquaculture industry. In addition, there is still room to increase the efficiency of breeding sites and increase their acceptance as the best source of seed.

\section{Conclusion}

The production of bivalve mollusc seeds is an opportunity area that needs to be improved. Bivalves have an important commercial role in the group of shellfish organisms. They are exposed to overexploitation and it is important to start looking forward to prevent any setback in their production. Thus, the research groups involved in the production of marine seeds should be given the task of highlighting the advantages of acquiring nursery seeds. More importantly, they should be promoting research that leads to understand the reproductive biology of marine species, with emphasis on those of commercial importance. In addition, researches have a duty to strengthen the working groups focused on improving production, cultivation, and growth techniques of marine seeds.

\section{Acknowledgement}

The author thanks to the Instituto de Investigaciones Oceanológicas - Universidad Autónoma de Baja California and the program "18va Convocatoria Interna", for the support and facilities provided for the realization of the manuscript.

\section{Conflict of Interest}

The author declares that there are no conflicts of interests regarding the publication of this paper.

\section{References}

1. FAO (2016) El estado mundial de la pesca y la acuicultura. Food \& Agriculture Org, Rome, Italy.

2. Helm MM, Bourne $N$ (2006) Cultivo de bivalvos en criadero. Un manual práctico. Food \& Agriculture Org, Rome, Italy.

3. FAO (2010) El estado mundial de la pesca y la acuicultura, vol. 1. Food \& Agriculture Org, Roma, Italy, p. 114

4. Oyinlola MA, Reygondeau G, Wabnitz CCC, Troell M, Cheung WWL (2018) Global estimation of areas with suitable environmental conditions for mariculture species. PLoS ONE 13, e0191086.

5. Utting SD, Millican PF (1997) Techniques for the hatchery conditioning of bivalve broodstocks and the subsequent effect on egg quality and larval viability. Aquaculture 155: 45-54.
Your next submission with Juniper Publishers will reach you the below assets

- Quality Editorial service

- Swift Peer Review

- Reprints availability

- E-prints Service

- Manuscript Podcast for convenient understanding

- Global attainment for your research

- Manuscript accessibility in different formats

( Pdf, E-pub, Full Text, Audio)

- Unceasing customer service

Track the below URL for one-step submission https://juniperpublishers.com/online-submission.php 